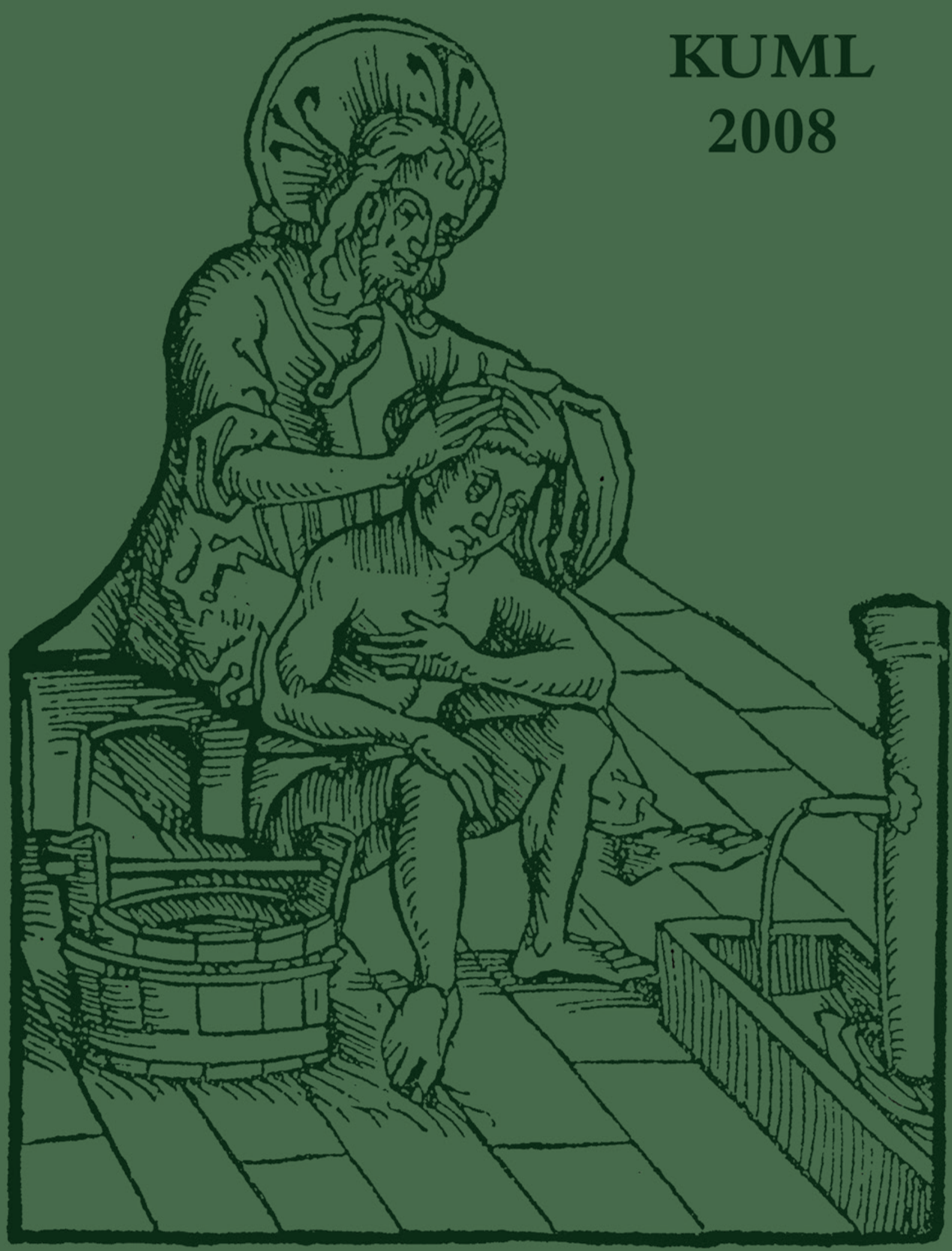




\section{KUML 2008 \\ Årbog for Jysk Arkæologisk Selskab}

With summaries in English

I kommission hos Aarhus Universitetsforlag 


\title{
Nationalmuseets nye udstilling: Danmarks Oldtid
}

\author{
Af JEANETTE VARBERG
}

Nationalmuseet har genåbnet udstillingen om Danmarks Oldtid, og for første gang siden 1973 har det været muligt at genfortælle vores ældste historie med landets fineste fund. Der er sket meget de sidste 35 år inden for det arkæologiske forskningsfelt, og derfor var der store forventninger til Nationalmuseets fremstilling af den nye viden. Derudover kan vores samtids teknologiske fremskridt potentielt fordre en helt ny og unik museumsoplevelse, der kan vække fortiden til live og tage os med på helt nye stemningsmættede visuelle oplevelser.

Modtagelsen af udstillingen i medierne har været blandet. Udstillingen deler vandene - enten kan man lide den eller ej. De negative røster påpeger, at udstillingen er gammeldags og upædagogisk. Her lægges vægten på det forhold, at tekst og illustrationer er barberet ned til et absolut minimum og genstandene, der er blevet fordoblet i udstillingen i forhold til den forrige, har fået lov til fuldstændigt at dominere. Udstillingen mangler ifølge kritikerne indlevelse og perspektiv, og bliver derfor lige så uvedkommende som et auktionskatalog i tandlægens venteværelse.

På den anden side står de, der er begejstret for udstillingens strenge æstetik og de mange nye genstande, der er sat flot op og belyst som kunstgenstande. Derfor er det heller ikke overraskende, at kunstkritikere er glade for udstillingen. Det fremhæves, at highlightparaden, som gennem hvert af udstillingens rum fremviser oldtidsfund i verdensklasse, er noget, som i høj grad har manglet i den gamle udstilling. I Steffen Heibergs anmeldelse i Politiken 1. juli 2008 konkluderer han: »I en globaliseret verden åbner udstillingen døren til vores fortid uden at synke ned i national navlebeskuelse.»

Alt dette vidste jeg, før jeg trådte over tærsklen til Prinsens Palæ ved Frederiksholms Kanal i det indre København. Brudstykker fra artikler, tv-udsendelser og samtaler dukkede op i kanten af min bevidsthed, men jeg lukkede af for støjen fast besluttet på at møde udstillingen på dens egne præmisser. 
Efter at være gået forkert, da jeg af gammel vane gik ind af den tidligere indgang til oldtidsudstillingen, fandt jeg endelig den nye indgang. I det lavloftede rum under første sals svalegang stilles man ansigt til ansigt med kronologiens fader C.J. Thomsens citater fra »Ledetraad til nordisk Oldkyndighed « fra 1836, og således konfronteret med fortidens ordning af genstande i sten, bronze og jern er tonen slået an til den nye udstilling.

Kontrasten er stor fra det første rums støvede mørke i et lidt ydmygt sidelokale til det andet rums højloftede og klare lys. Rummet med den ældste stenalder er stort og åbent, og det er nemt og hurtigt at orientere sig og forstå rummets opbygning.

Yderst løber det narrative spor hen over nyrestaurerede vægge, hvor lækkert oplyste glasplancher i næsten lyrisk opstrammet tekst indleder hvert rum med et minimum af ord. Grøn er stenalderens farve, så længe det er grønt på plancherne, så er det stenene, der hersker i udstillingen. Violet er bronze, og blå er jern.

I midten af rummet står museets fineste genstande, som for eksempel de to imponerende urokseskeletter eller de helt unikke miniatureravdyr fra ældre stenalder samlet for første gang i udstillingen.

På indervæggen dominerer store montrer fyldt til bristepunktet med flint. Her er det mangfoldigheden, der er i fokus, og i det spor kan man fornemme tyngden i museets samlinger, selvom størstedelen stadig ligger hen på magasinerne. Genstandene følges af sparsom information og uden uddybende beskrivelse, som man så det på helt gamle udstillinger fra første halvdel af det 20. århundrede.

De tre spor: fortællingen, highlights og mangfoldigheden spejler sig i hinanden og skaber dynamik på tværs af kronologien. Den opbygning følger den besøgende igennem næsten alle 24 rum, og på en eller anden måde føles det trygt, fordi det hele er overskueligt, og det er nemt at finde de helt unikke fund i midten af hvert rum.

Museets målsætning om at skabe et stilrent overblik ses tydeligt i opbygningen, og her kan man sige, at det virkelig er lykkedes for teamet af Nationalmuseets ansatte og arkitekterne fra firmaet Schmidt, Hammer og Lassen at skabe et klart og formfuldendt bekendtskab med oldtiden. 18 timers tekst i den gamle udstilling er barberet ned til $1 \frac{1}{2}$ time i den nye, og dermed er der ingen fare for, at gæsten fortaber sig i lange teoretiske udredninger om fortidens samfund. Nationalmuseets slogan til udstillingsguiden er derfor også meget passende: Danmarks Oldtid på 60 minutter. Det er nemt for turister at gå udstillingen igennem, besøge butikken og nå deres krydstogtskib på Langelinie inden afsejling klokken 19.00 . 
Efterhånden som man går frem i tid, ændres den første begejstring langsomt til irritation, for hvert rum er en gentagelse af det forudgående uden nogen variationer andet end dem, den fredede bygning påtvinger arkitekterne. Nye montrer fremhæver tingenes fremmedartede skønhed, men fortællingerne om mennesket bag synes at gå tabt i arkitekternes strenge streg gennem rummene - alt liv er som visket ud af udstillingen.

Genstandene forandres, og den grønne farve ændres til violet i afsnittet om bronzealderen, men det er, som om forandringerne ikke rigtigt træder tydeligt frem andet end for fagfolk, der kan deres genstandskronologi. Ud over flere oldtidsskeletter, så er mennesket fuldstændigt fraværende i udstillingen, og de eneste uddybende illustrationer er en forsigtig udgravningsplan på indervæggen i ny og næ.

I det dunkle rum, hvor bronzealderens egekister svæver i lag, kommer man endelig helt tæet på mennesket i oldtiden. Her ligger de i deres kister med hår, huer og uldtøj og fortæller en mere end 3000 år gammel historie om glemte slægter i det jyske land. Det er helt enestående at se så mange oldtidsmennesker samlet i samme rum, og dets lige findes ikke i Europa. Men heller ikke her er det lykkedes at få formidlet de historier ud, som hver af de syv oldtidsmennesker repræsenterer. Den korte tekst tillader kun få stumper af den store fortælling at komme ud til publikum - en fortælling som vi ved, at Nationalmuseets arkæologer forsker i og brænder for at fortælle om. Derfor virker beslutningen om den ultrakorte tekst og fraværet af illustrationer selvmodsigende, eftersom nogle af dem der ved mest om Danmarks oldtid kun har fået lov til at formidle ganske lidt af deres viden videre til de besøgende.

Forestillingerne om fortiden går tabt mellem teksten på ydervæggen og fundene i rummet. Afstanden mellem plancherne og genstandene er kun et par meter, men menneskets historie drukner i en parade af oldsager med nummer, mens de besøgende driver med strømmen med overblikket i behold - for der er ingen informationer, der kan rette deres blik mod detaljen.

Fokusgruppeundersøgelser efterlyste mere formidling af ånd og tro i udstillingen, og i udvalgte rum er det så forsøgt. Bronzealderens religiøse forestillinger om solens rejse over himlen om dagen og under havet om natten er en fortælling så mættet med stemning, mystik og forunderlig fantasi, at den er som skabt til den udstillingsdel.

Derfor ser jeg mig nysgerrigt omkring i rummet, hvor solvognen, bronzealderens ikon, står på et lille oplyst podie i midten af rummet. Den står sammen med et par andre montrer og synes lidt undseelig i forhold til dens betyd- 
ning. Langs væggene hænger bronzealderens mest sælsomme og mærkelige fund, og fra endevæggen brager en blodorange plexiglas sol ud over udstillingen. Jeg føler mig næsten hensat til et af Michael Strunges surrealistiske digte i væggens neonlys.

Alligevel lægger man ikke mærke til sammenhængen mellem genstandene og solen, for ingen af bronzealderens fabelbilleder bevæger sig hen over solhimlen, og den besøgende er igen overladt til små sort-hvide plancher for at få en ide om, hvad det hele handler om. Stemning og ånd skal fornemmes og iscenesættes for at det virker, og solen er sammen med de pænt ordnede oldsager i montrerne løsrevet fra fortællingen, og derfor virker solvæggen som et anonymt tapet i stedet for at være integreret i rummet.

Meget bedre bliver det i afsnittet om jernalderens moseofringer, hvor Gundestrupkedlen står flot oplyst og omkranset af en fugtigt dampende mose. En besynderlig melodi lokker én videre ind i et andet rum, hvor Huldremosekvinden ligger i sin ulddragt. Lyset i rummet er for en gangs skyld godt, og man kan næsten aflæse det sidste suk fra hendes forpinte læber. Mosens lyde slår stemningen an, og her kommer man rigtig tæt på fortiden, og der er plads til fordybelse og refleksion over tidens forgængelighed.

I de følgende rum bugner udstillingen af jernalderens rige fund. I et sidekapel er Hjortspringsbåden lige akkurat klemt ind. Fundet er unikt, men det er svært at se i det lille anneks, hvor dårligt lys gemmer Danmarks ældste skib i et grumset halvmørke.

Den sidste del af udstillingen bærer i høj grad præg af Nationalmuseets rigdomme. Den ene pragtfulde genstand afløser den anden, og alle genstandene fortjener en plads i highlightparaden. Men mange fund er blevet henvist til vægmontrernes klemte pladser. De fine ting drukner i hinandens pragt, og det exceptionelle bliver ordinært på de overfyldte glashylder.

Derfor er den sidste del også en ægte tour de force gennem fortidens skatte, og øjet bliver konstant tiltrukket af glimtende guld og sølv. Det er imponerende at træde ind i guldrummet og derefter lade blikket glide over vikingetidens sølvskatte i næste rum, og selvom pladsen er trang, så er det stadig vanvittigt flot at se på.

Genstandenes magt er forførende og smuk, men igen mangler indblikket i fortidens samfund. End ikke i det lille afsnit om Danmarks mest berømte epoke - vikingetiden - ser man lidt af fortidens folk. I sidste rum slutter fortællingen om Danmarks oldtid af med Jellingdynastiets storhed. I en montre står det lille sølvbæger fra Jellingehøjens gravkammer ensomt mod en sort bagvæg og skal alene bære beretningen om Gorm den Gamle og Harald Blåtand sam- 
men med et par planchelinjer. Selv om sølvbægeret er fint, så rummer det alene ikke meget drama.

Vikingetiden slutter, før den begyndte, og så er jeg tilbage igen under svalegangen i selskab med Hr. Thomsen og hans ordning af oldtiden. Udstillingen er en sand hyldest til Nationalmuseets grundlægger, der satte skattene i system og lagde kimen til den arkæologiske forskningstradition. På bænken med udsigt til hans 172 år gamle citater er det tydeligt, at hans Ledetraad til nordisk Oldkyndighed lige så godt kunne have været den nye udstillings manuskript. Den viden, vi i dag har opbygget om fortidens samfund og mennesker, er kun flygtigt berørt, og formidlingen er overladt til den besøgendes egen fantasi.

Det er den ellers flot opsatte og strømlinede arkitekttegnede udstillings største mangel. Man går ind og ud af rum og ser, hvad mennesker har efterladt sig af spor i landskabet, men ikke en eneste tegning eller illustration viser, hvordan mennesket har levet eller set ud i fortiden. Stemningsfulde billeder af naturen følger én rundt i rummene, men paradoksalt nok er det altid tomme landskaber uden spor af mennesker.

Det er en distanceret, retrospektiv og elitær holdning til formidlingen af fortiden at tro, at tingene i sig selv er nok til at skabe en forestilling om forhistoriens mennesker hos de besøgende - lige meget hvor fantastiske genstandene er i sig selv. Det bevidste fravalg af rekonstruerede fremstillinger af mennesker, deres boliger, skibe, vogne og dyr er ganske enkelt en fejl, som i den grad har affødt den massive kritik, som museet har måttet slås med efter åbningen. Arkitekternes stræben efter formfuldendthed har vejet tungere end arkæologernes viden, og det bærer udstillingen tydeligt præg af. Der er intet legende eller skævt i opbygningen, og frem for alt er den uden liv. Arkitekternes dominerende visioner er udført på bekostning af formidlingen.

Dertil kommer, at den eneste interaktivitet i den splinternye udstilling på Nationalmuseet er trykknapperne, der åbner glasdørene mellem hvert rum, og selvom interaktive installationer bevidst er skåret væk af økonomiske grunde, er det ikke en gyldig undskyldning for ikke at bruge illustrationer i udstillingen eller opsætte audioguides, der fortæller uddybende ved udvalgte montrer.

Havde der været økonomi til interaktive miljøer i forbindelse med genstandene, hvor animationer, film og supplerende tekster kunne ledsage genstandene på eksempelvis integrerede touchscreens, så ville udstillingen åbne mere op for de besøgende. På museets hjemmeside er der produceret nogle små filmklip, hvor museumsinspektør Flemming Kaul fortæller om blandt andet Egtvedpigen og Huldremosekvinden. De er flot klippet og fortalt og tillader et 
blik ind i fortiden, som ikke er til stede i udstillingen. Hvis de film var tilgængelige i forbindelse med de udstillede genstande, vil Danmarks Oldtid få en helt ny dimension.

Det diskuteres i denne tid, hvordan museer kan benytte sig af supplerende teknologiske installationer uden at gå i den digitale fælde, hvor teknologien kun er sat op for teknologiens skyld. De kritiske røster kommer ofte fra den xldre generation, der ikke er opvokset med teknologien, og som måske ikke er helt tryg ved de nye medier og dermed godt kan være foruden. Men der er ingen tvivl om, at de yngre generationer, der er født ind i en digital tidsalder, ikke har samme holdning; digitale medier er en naturlig del af deres dagligdag. Teknologien er kommet for at blive, og jo før vi lærer at anvende den integreret og klogt i vores udstillinger jo bedre.

Derfor er det problematisk, at Nationalmuseet i vores tid ikke kan rejse midlerne til at indrette en moderne museumsudstilling med plads til digital formidling.

Dermed stiller jeg mig op i rækken af kritikere af udstillingen. Jeg ville så gerne kunne sige, at udstillingen er fantastisk, for der har ligget et stort arbejde bag. Men når jeg vandrer gennem Prinsens Palæs knagende gange og spejler mig i glas og krom, så mangler jeg indsigten i mennesket bag genstanden - jeg mangler vel det, man kalder for livet. 